\title{
ARISTOTELIS
}

\section{CATEGORIAE ET TOPICA CUM PORPHYRII ISAGOGE}

EX RECENSIONE

\section{IMMANUELIS BEKKERI}

\author{
SEORSUM EDITA.
}

\section{BEROLINI}

TYPIS ET IMPENSIS GE. REIMERI

A. 1843. 
